\title{
Self-rated health, ethnicity and social position in a deprived neighbourhood in Denmark
}

\author{
Pernille T Andersen ${ }^{1 *}$, Carsten K Bak², Susanne Vangsgaard ${ }^{1}$, Unni Dokkedal ${ }^{3}$, Pia V Larsen ${ }^{4}$
}

\begin{abstract}
Background: In recent years the close connection between SES and differences in health between ethnic groups have been subject to growing interest among researchers, and some studies have found an association between ethnicity and long term illness and poor health. However, there is limited research-based knowledge about health and illness in ethnic groups in Denmark and about ethnic Danes living in deprived neighbourhoods. The purpose of this study is to investigate associations between self-rated health and ethnicity and social position in a deprived neighbourhood in Denmark in which a relatively largely proportion of the residents are immigrants.

Methods: This study investigates the association between self-rated health used as dependent variable and ethnicity and social position (defined as index for life resources) as the independent variables. The analyses are based on data collected in a survey in a geographically bounded and social deprived neighbourhood,

Korskaerparken, located in the municipality of Fredericia in Denmark. The sample consisted of 31\% of the residents in Korskaerparken and of these 29\% have an ethnic background other than Danish.

The analyses were conducted using logistic regression adjusting for confounding variables.

Results: This study indicates no significant association between ethnicity and having poor/very poor self-rated health.

On the other hand the study confirms that a strong and significant association between the number of residents' life resources and their self-rated health does indeed exist. The results clearly suggest that the more life resources an individual has, the lower is the risk of that individual reporting poor health.

Conclusion: The results show a strong association between the residents' number of life resources and their selfrated health. In this study, we were not able to identify any association between ethnicity and self-rated health, i.e. our results suggest that ethnicity does not constitute an explanation to differences in self- rated health.
\end{abstract}

\section{Background}

It is well known that health has a social gradient in the sense that people with low socio-economic status (SES) have more health related problems than people with high SES [1,2]. Extensive research into socioeconomic inequalities in health shows that people with high SES live longer and are healthier than people with low SES, who tend to die younger and suffer more illnesses and disabilities [3-6].

In recent years the close connection between SES and differences in health between ethnic groups have been subject to growing interest among researchers [7], and

\footnotetext{
* Correspondence: ptandersen@health.sdu.dk

'Unit for Health Promotion Research, Institute of Public Health, University of Southern Denmark, Niels Bohrs Vej 9-10,6700 Esbjerg, Denmark

Full list of author information is available at the end of the article
}

some studies have found an association between ethnicity and long term illness and poor health $[8,9]$. Denmark has, since the beginning of the $20^{\text {th }}$ century, received immigrants from more than 200 different countries. Approximately half of the immigrants originate from non-western countries such that in 2007 the proportion of adult Non-western immigrants (NWIs) constituted 3.3\% of the Danish population [10]. Despite the multi-ethnic composition of the Danish population and the fact that many immigrants live in deprived residential areas there is very limited research-based knowledge about health and illness in ethnic groups in Denmark [11-14] and about ethnic Danes living in deprived neighbourhoods $[15,16]$.

Contributory causes for the lack of research-based knowledge are that it is commen to leave out NWIs in

\section{() Biomed Central}


national health surveys, and that there are often so few NWIs in the samples that attempts to generalize are non productive [10]. Literature on health among ethnic minorities in Denmark typically involves a comparison between the ethnic minorities and the (average) majority of ethnic Danes [11,12,17]. Consequently, most studies are based on the assumption that ethnicity/culture is one of the main reasons for health inequality. Singhammer's findings show that the health status is poorer among NWIs than among ethnic Danes in particular, his study shows that the risk of temporary mental illnesses, such as depression and anxiety, are two to four times higher among NWIs compared to ethnic Danes [11].

Differences in health, in terms of morbidity as well as mortality, across ethnic groups have been documented in studies from the United States [18-20] and the United Kingdom [21,22] and to a lesser extent from Europe.

A number of Scandinavian studies have addressed the association between ethnicity and self-rated health [23-25]. The studies show that ethnicity is associated with poor self-rated health, and that socio-economic status only explains part of the association, while another part of the association is explained by acculturation and discrimination.

Although there exist substantial data material on differences across ethnic groups, the factors underlying the differences - especially the role socioeconomic inequalities might play - remain contested. Many researchers still focus on cultural and/or genetic explanations for the differences $[26,27]$ partly due to lack of good data on socioeconomic position which has impeded the investigations of ethnic inequalities in health. Arguments for and against various indicators of socioeconomic position have been given $[28,29]$, these arguments typically aim to identify the effect of a specific socioeconomic determinant on health while adjusting for one or more other indicators. While this approach may have merits in its own right, it nevertheless overlooks the complex socioeconomic pathways through which health inequalities are produced $[7,30]$.

Rather than studying the merits of one specific socioeconomic indicator, we discuss the use of a resource index to measure social position. We believe that an index can provide a better understanding of the complexity of the effect of social position on health by including more socioeconomic indicators in the same index [31].

We regard social position from a generic resource perspective whereby resource allocation within the population is assumed to influence the individual's living conditions in terms of aiding health, well-being etc. The resource perspective is closely connected to the Nordic welfare model which is centred around resource allocation within the population as a whole and focussing on resource development rather than economic redistribution [32-35]. The resource perspective is based on the idea that an individual is an actively acting being with self-defined goals, who in his or her strive to reach these goals is limited by the resources available [33,36].

Using a resource index for measuring social position has a number of advantages $[37,38]$. In contrast to traditional categorizations based on occupational positions, the resource index for social position allows individuals outside the labour market to be positioned as well as working individuals. Also, an index can include information on family structure and resources within the family, e.g. economic deprivation, which constitute important aspects with regards to social position. A further advantage is that an index measures social position on a continuum which gives more individual measures than a set of rigid social position categories [39]. And last but not least, individuals are evaluated based on their total amount of non-prioritised resources allowing the possession of one resource to make up for a lack of another.

The purpose of this article is to investigate associations between self-rated health and ethnicity and social position in a deprived neighbourhood in Denmark in which a relatively large proportion of the residents are immigrants.

\section{Methods}

The analyses of this article are based on data collected from the geographically bounded and social deprived neighbourhood Korskærparken, located in the municipality of Fredericia in Denmark. A total of 1842 persons live in the neighbourhood, of these 1321 are adults, $36.7 \%$ are immigrants (364 adults and 311 children under the age of 18$), 4.7 \%$ are unemployed, $34.2 \%$ are single parents, and $55.2 \%$ have a disposable income of less than the median disposable income in Denmark (DKK 150000 per year) [40]. Of the 364 adult immigrants $224(61.5 \%)$ receive either social benefits (the majority), incapacity benefits or sickness benefits.

The target group was defined as adults above the age of 16 in Korskærparken. The sample consisted of $31 \%$ of the residents: 408 agreed to take part in the survey but only 404 answered the questionnaire (Figure 1). Residents with an ethnic background other than Danish made up $29 \%$ of the sample, of these seven individuals were from the Nordic countries and further five from the rest of Europe (excluding the former Yugoslavia). It was not registered whether the residents with non-Danish ethnic backgrounds were immigrants or descendents.

The data collection was carried out in the spring of 2008 by the consultancy firm Capacent/Epinion, and the research project is financed by the municipality of Fredericia. Information on the survey was announced in advance throughout the neighbourhood. The sampling 


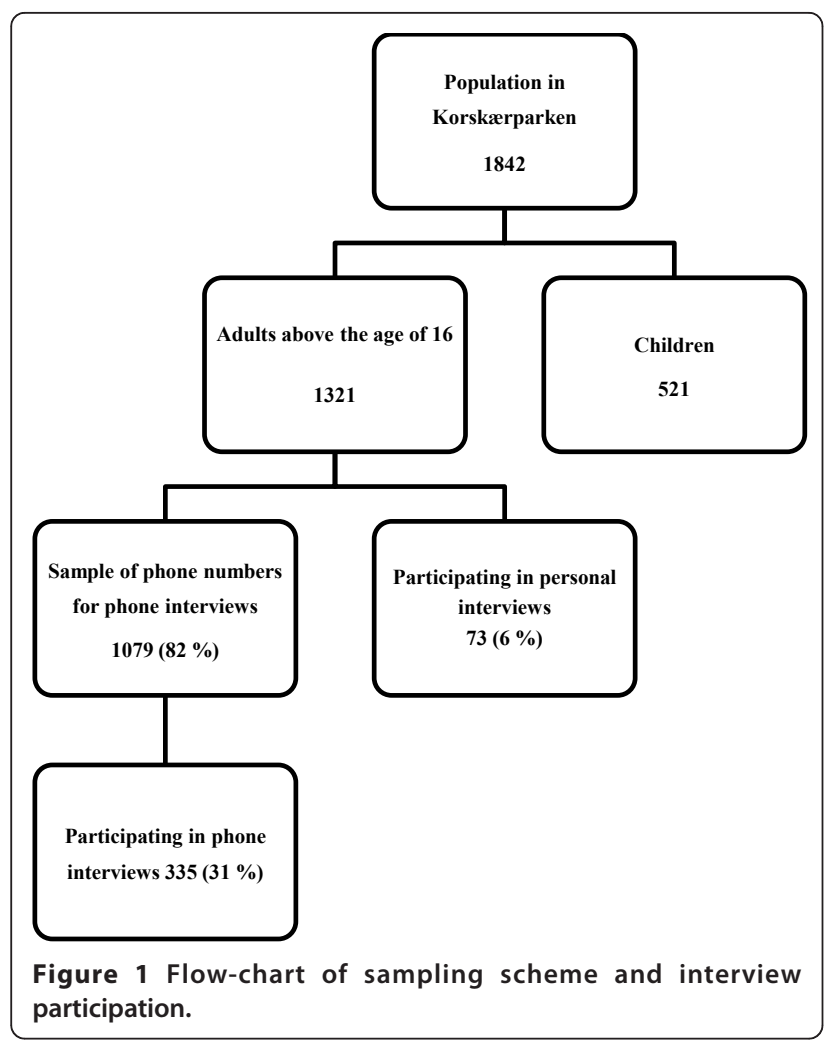

was stratified on ethnicity. Data were primarily collected via telephone interviews, and secondary via personal interviews to include those who were not listed in the telephone directory to avoid possible bias. The interviews were carried out by a multilingual team of interviewers with diverse ethnic backgrounds, who could assist with linguistic difficulties related to understanding the questionnaire. It was not registered which of the participants were interviewed by phone and which in person. From 12 households two members were sampled, and from one household three members were sampled. It was not registered which of the participants came from the same households.

\section{Measures}

\section{Questionnaire Development}

The questionnaire used in the study was constructed in line with existing research [41] and designed to collect information on health indicators, health behaviours, social factors and use of welfare services. The questionnaire, consisting of 50 questions, was developed in connection with an intervention study in Korskærparken running from 2008 to 2011.

\section{Self-rated health}

Self-rated health is defined as an individual's own view of his or her state of health. Self-rated health is an often used and relatively precise state of health indicator, and is a well-know predictor of mortality and morbidity $[42,43]$. It can be argued that a negative opinion of one's state of health increases the risk of death, cancer, and heart disorders, which lead to an increased use of the healthcare system and incapacity benefits, more absenteeism, a higher level of medicine use, and reduce the individual's general ability to function, which further lead to a greater risk of unemployment [36].

The questionnaire included the question on self-rated health "How would you assess your present state of health?" (Options: "very good", "good", "fair", "poor", and "very poor"). Due to the small sample size, it was later dichotomized by combining the answers "very good", "good" and "fair" into one category and the answers "poor" and "very poor" into another, as is common in the public health area.

\section{Social Position}

To measure social position we use an index for life resources based on the index used in a report on selfrated health and inequality in health in the County of Aarhus [36]. The index is a resource index, which in addition to socioeconomic factors e.g. education, job and income also includes family conditions e.g. children and marital status. A similar approach is used in Oakes \& Rossi [39], and it is in line with Scandinavian welfare research. The index is based on a formative measurement model where the theoretical variable "social position" is defined by the resource variables included in the index, as opposed to a reflective measurement model where it is assumed that the variables included in the index reflect an underlying theoretical variable (latent variable).

\section{Index for life resources}

We use a slightly adjusted version of the index by Larsen [36] in that we emphasize economic deprivation and leave out home ownership since all of the homes in the area are rental. The following variables are included in the index for social position: living with others, children, education, occupational income, job category disposable income, and economic deprivation (Table 1).

The minimum disposable income of DKK 3000 per month after fixed expenses (approx. USD 630/€ 400 in

Table 1 Variables applied in the index for life resources

\begin{tabular}{lcc}
\hline & Resource & $\begin{array}{c}\text { Lacking } \\
\text { resource }\end{array}$ \\
\hline Living with others & Yes & No \\
Has children & Yes & No \\
Has studied beyond primary school & Yes & No \\
Has occupational income & Yes & No \\
Is white-collar worker or self-employed & Yes & No \\
Has monthly disposable income $\geq$ DKK 3 & Yes & No \\
O00 & & No \\
Suffers no economic deprivation & Yes &
\end{tabular}


2008 currency) is the study population median and was used in order to facilitate a comparison between the economicly worse-off and better-off groups of residents in deprived residential areas such as Korskærparken. Economic deprivation is here defined as the situation where a family during the past two months for economic reasons have been unable to pay their bills, cope with incidental expenses, buy birthday presents, afford dental check-ups or buy medicine, clothing, shoes etc.

The index for life resources can attain values from zero to seven. A low index value indicates an individual with few resources a high index value indicates an individual with many resources. We grouped the variable into an ordinal variable with the categories 0-1, 2, 3, 4-7 resources, respectively.

\section{Statistical analyses}

An exploratory analysis included frequency tables, cross tabulations and chi-square tests.

The relationship between self-rated health and ethnicity was analysed as well as the relationship between self-rated health and the index for life resources. We checked for effect modification between ethnicity and life resources. The analyses were conducted using logistic regression. Age, gender and ethnicity were considered the main relevant confounders and were adjusted for.

The statistical analyses were carried out using SPSS version 17.

\section{Results}

The demographic characteristics of the sample are listed in Table 2.

Table 2 Descriptive statistics for the study variables

\begin{tabular}{llrr}
\hline Variable & & N & $\%$ \\
\hline Gender & Male & 196 & 48.5 \\
& Female & 208 & 51.5 \\
Age & 16-24 years & 59 & 14.8 \\
& 25-44 years & 150 & 37.6 \\
& 45-64 years & 109 & 27.3 \\
& 65+ & 81 & 20.3 \\
Ethnicity & Different ethnic background & 118 & 29.2 \\
& Europe excluding former Yugoslavia & 12 & \\
& Other & 106 & \\
Life resources & 286 & 70.8 \\
& Ethnic Danes & 22 & 8.2 \\
& 0-1 & 42 & 15.7 \\
& 2 & 79 & 29.6 \\
& 3 & 124 & 46.4 \\
Self-rated health & 343 & 84.9 \\
& 4-7 & 250 & 61.9 \\
& Very good/good/fair & 93 & 23.0 \\
& Fair good/good & 61 & 15.1 \\
\hline
\end{tabular}

About $62 \%$ of the participants reported having good/ very good health, while $15 \%$ reported having poor/very poor health. Around $30 \%$ of the participants had a different ethnic background than Danish. The majority of non-Danish residents came from Afghanistan, Iraq, former Yugoslavia, Somalia and Sri Lanka. A small group of 12 came from Europe excluding former Yugoslavia. The sample was almost equally distributed in terms of gender. The age group 25-44 years constitutes the largest group of participants (38\%). Effect modification between ethnicity and life resources was not found $(\mathrm{p}=0.709)$.

As seen in Table 3, this study indicates no significant association between ethnicity and having poor/very poor self-rated health.

Table 4 shows a strong association between life resources and self-rated health. The results clearly suggest that the more life resources an individual has, the lower is the risk of that individual reporting poor health. The risk of an individual with no or only one life resource reporting poor/very poor health is almost 14 times greater than the risk of an individual with many life resources (4-7). The risk of an individual with 2 or 3 life resources reporting poor/very poor health is 5 and 3 times greater, respectively, than for individuals with many life resources.

\section{Discussion}

The survey carried out in Korskærparken in the municipality of Fredericia has confirmed a strong association between residents' number of life resources and their self-rated health. The risk of a resident with no or only one life resource reporting poor/very poor health is about 14 times greater than the risk of a resident with many life resources (4-7), and the risk of a resident with 2-3 life resources reporting poor/very poor health is 5 and 3 times greater, respectively, than the risk of a resident with many life resources. We were not able to identify an association between ethnicity and self-rated health in Korskærparken. Our analyses suggest that ethnicity and culture are not primary reasons for differences in self-rated health when the study population come from social deprived neighbourhoods. The results we have found in this study are consistent with the results obtained by Larsen [36], even though the study by Larsen differs from our study in certain ways. Our study concerns a socially deprived neighbourhood hosting a relatively large number of residents with few resources, while the study discussed by Larsen concerns the general population in a county. Also, the resource index we use includes slightly different economic variables than Larsen's [36], e.g. disposable income and deprivation. Finally, we tested for the influence of ethnicity, which was not considered in Larsen [36]. 


\begin{tabular}{|c|c|c|c|}
\hline & & $\begin{array}{l}\text { Adjusted effect }^{1} \\
\text { OR }(95 \% \mathrm{Cl}) \\
\mathrm{N}=263\end{array}$ & $\begin{array}{l}\text { Effect adjusted for life resources }{ }^{2} \\
\text { OR }(95 \% \mathrm{Cl}), \\
\mathrm{N}=263\end{array}$ \\
\hline \multicolumn{4}{|l|}{ Ethnicity } \\
\hline & Other ethnic background & $1.79(8.89-3.57)$ & $2.03(0.87-4.74)$ \\
\hline & Ethnic Danes & Reference & Reference \\
\hline
\end{tabular}

${ }^{1}$ Model was adjusted for the effect of age and gender.

${ }^{2}$ Model was adjusted for the effect of age, gender and life resources.

\section{Strengths of the study}

The relatively high number of participants with an ethnic background other than Danish constitutes an important feature of the Korskærparken survey in itself, as this section of the population often refrain from taking part in national and regional health surveys. We believe that the high attendance of residents with non-Danish ethnic background in part is a result of the data collection strategy, i. e. a combination of telephone and personal interviews carried out by multilingual interviewers. We believe that giving priority to answers from people with other ethnic background than Danish has a great impact on the results in the analysis. The different data collection methods and more answers from this group could be important in the long run to get a more comprehensive picture of the health state of NWIs in deprived neighbourhoods.

One purpose of our analysis was to investigate whether ethnicity is associated with self-rated health. The data from Korskærparken include a number of comparable social groups in terms of income, education, deprivation and neighbourhood characteristics, unlike other large-scale population studies on health in ethnic minority groups in Denmark, e.g. Singhammer [11]. One reason why Singhammer found large differences between ethnic Danes and ethnic minorities whereas our analyses show no significant differences might be that the large-scale surveys compare ethnic minorities to average ethnic Danes, who have a relatively high number of life resources, instead of comparing them to groups of ethnic Danes with comparable social position and comparable number of life resources.

\section{Limitations}

The strengths of the study are balanced by some methodological limitations. The most important being that the

Table 4 Risk of having poor/very poor self-rated health in relation to life resources

\begin{tabular}{lrrr}
\hline & $\begin{array}{r}\text { Adjusted effect } \\
\text { OR }(95 \% \mathrm{CI})\end{array}$ & P-value \\
$\mathrm{N}=263$ & \\
\hline Life resources & $0-1$ & $13.56(4.00-45.94)$ & $<0.01$ \\
& 2 & $4.67(1.63-13.37)$ & $<0.01$ \\
3 & $3.48(1.33-9.08)$ & 0.01 \\
$4-7$ & Reference & \\
\hline
\end{tabular}

${ }^{1}$ Model was adjusted for the effect of age, gender and ethnicity. resource-index we use is based on theoretical considerations alone and is not validated. We would need more data from different contexts in order to validate it which further research hopefully will contribute to. The measure of self-rated health is based on a single-item question which might have some drawbacks compared to e.g. SF36 . However, the single-item question is a validated and used measure in epidemiology and social science as a global measure of general health status [44]. Studies show that the single-item measure is a strong and independent predictor of morbidity and mortality [45]. The single-item measure is also used in studies comparing health status between different ethnic groups [46].

Further limitations are connected with the data collection in the survey. In the data collection, it was not registered which of the respondents were interviewed by telephone and which by personal interviews. The type of interview could have an effect on the answers given by the respondents. Among the respondents with non-Danish background, it was not registered whether they were first or later generation immigrants. Again this could have an effect on the answers given. Further, it was not registered who belong to the same household. The clustering could lead to bias and thus affect the results of the analyses. Finally, it was not possible to compare different ethnic groups as there are too few of each nationality to stratify the analysis on ethnicity. With a larger data set it would have been relevant to investigate the heterogeneity between ethnic groups further, in order to analyze differences in health beliefs, health literacy and health behaviour.

It was not an aim of this study to compare the results from Korskærparken with results from a larger study population (e.g. the entire municipality/region), or to results from other more well-off local areas, however, in future research it would be relevant to make this kind of comparisons [47] Also, we would have liked to analyse the differences in gender-effect between various ethnic groups but the sample is too small to stratify on ethnic groups.

\section{Conclusion}

By using a resource index to measure social position in a deprived neighbourhood, we have contributed with new knowledge about the association between self-rated health and social position and ethnicity, respectively. 
The results show a strong association between residents' number of life resources and their self-rated health. In this study, we were not able to identify any association between ethnicity and self-rated health, i.e. our results suggest that ethnicity does not constitute an explanation to differences in self- rated health.

The results of this research should be considered exploratory on which to base further extended studies. Such studies may consider the effect on self-rated health by various intervening variables such as psycho-social stress, long-term illnesses, health problems and life style (e.g. smoking, exercise).

The results underline the need of further testing and developing an index to measure social position and ethnicity in relation to health.

\section{Author details}

${ }^{1}$ Unit for Health Promotion Research, Institute of Public Health, University of Southern Denmark, Niels Bohrs Vej 9-10, 6700 Esbjerg, Denmark. ²Danish Center for Rural Research, Department of Environmental and Business Economics, University of Southern Denmark, Niels Bohrs Vej 9-10, 6700 Esbjerg, Denmark; Health office. Municipality of Fredericia, Gothersgade 20, 7000 Fredericia, Denmark. ${ }^{3}$ Unit for Health Promotion Research, Institute of Public Health, University of Southern Denmark, Niels Bohrs Vej 9-10, 6700 Esbjerg, Denmark. ${ }^{4}$ Research Unit for General Practice, Institute of Public Health, University of Southern Denmark, J. B. Winsløws Vej 9A, 5000 Odense C, Denmark.

\section{Authors' contributions}

PTA, CKB are principal investigators, participated in the design of the study and drafted the manuscript; SV health promotion practitioner for the Korskær project in Municipality of Fredericia; UD and PVL performed the statistical analysis. All authors read and approved the final manuscript.

\section{Competing interests}

The authors declare that they have no competing interests.

Received: 13 May 2010 Accepted: 25 January 2011

Published: 25 January 2011

\section{References}

1. Syed HR, Dalgard OS, Hussain A, Dalen I, Claussen B, Ahlberg NL: Inequalities in health: a comparative study between ethnic Norwegians and Pakistanis in Oslo, Norway. Int J Equity Health 2006, 5:7.

2. Davey-Smith G, Blane D, Bartley M: Explanations for socioeconomic differences in mortality: evidence from Britain and elsewhere. Eur J Public Health 1994, 4:131-44.

3. Dalstra JA, Kunst AE, Borrell C, Breeze E, Cambois E, Costa G, Geurts JJ, Lahelma E, Van Oyen H, Rasmussen NK, Regidor E, Spadea T, Mackenbach JP: Socioeconomic differences in the prevalence of common chronic diseases: an overview of eight European countries. Int J Epidemiol 2005, 34(2):316-26.

4. Demakakos P, Nazroo J, Breeze E, Marmot M: Socioeconomic status and health: the role of subjective social status. Soc Sci Med 2008, 67(2):330-40.

5. Siegrist J, Marmot M: Health inequalities and the psychosocial environment-two scientific challenges. Soc Sci Med 2004, 58(8):1463-73.

6. Mackenbach JP, Kunst AE, Cavelaars AE, Groenhof F, Geurts JJ: Socioeconomic inequalities in morbidity and mortality in western Europe. The EU Working Group on Socioeconomic Inequalities in Health. Lancet 1997, 349(9066):1655-9.

7. Nazroo JY: The structuring of ethnic inequalities in health: economic position, racial discrimination, and racism. Am J Public Health 2003, 93(2):277-84.

8. Senior PA, Bhopal R: Ethnicity as a variable in epidemiological research. BMJ 1994, 309(6950):327-30.
9. Sundquist J, Johansson SE: The influence of country of birth on mortality from all causes and cardiovascular disease in Sweden 1979-1993. Int J Epidemiol 1997, 26(2):279-87.

10. Singhammer J, Bancila D: Associations between stressful events and selfreported mental health problems among non-Western immigrants in Denmark. J Immigr Minor Health 2009.

11. Singhammer J: Etniske minoriteters sundhed [Health of ethnic minorities] AArhus: Centre for Public Health, Central Denmark Region; 2008.

12. Folmann NB, Jørgensen T: Etniske minoriteter: sygdom og brug af sundhedsvæsenet [Ethnic minorities: illness and use of the health system] Copenhagen: Danish National Board of Health; 2006.

13. Hansen AR, Kjoller M: Sundhed blandt etniske minoriteter: Resultater fra sundheds- og sygelighedsundersøgelsen 2005 (SUSY 2005). [Health among ethnic minorities: results from the health and morbidity survey 2005 (SUSY 2005)] Copenhagen: National Institute of Public Health; 2007.

14. Ingerslev O: Sundhedsforhold blandt indvandrere [Health conditions among immigrants]. In Integration i Danmark omkring årtusindskiftet: indvandrernes møde med arbejdsmarkedet og velfærdssamfundet [Integration in Denmark at the turn of the millenium: the immigrants encounter with the labor market and the welfare society]. Edited by: Viby Mogensen G, Matthiessen PC. Copenhagen. Rockwool Foundation Research Unit, Aarhus University Press; 2000:222-51.

15. Pedersen PV, Christensen Al, Hesse U, Curtis T: SUSY UDSAT. Sundhedsprofil for socialt udsatte i Danmark 2007 [Health profile of the socially marginalised in Denmark 2007] Copenhagen: National Institute of Public Health, University of Southern Denmark and The Council for Socially Marginalised People; 2008.

16. Central Denmark Region: Sociale forskelle i sundhed. Anbefalinger fra det midlertidige udvalg vedrørende sociale forskelle i sundhed [Social differences in health. Recommendations from the temporary committee on social differences in health] Denmark: Central Denmark Region; 2009.

17. Kjøller M, Juel K, Kamper-Jørgensen F: Folkesundhedsrapporten Danmark 2007: 2004, 2005, 2006 [The Public Health Report Denmark 2007: 2004, 2005, 2006] Copenhagen: National Institute of Public Health; 2007.

18. Rogers RG: Living and dying in the U.S.A.: sociodemographic determinants of death among blacks and whites. Demography 1992, 29(2):287-303

19. Sorlie $\mathrm{P}$, Rogot $E$, Anderson $\mathrm{R}$, Johnson NJ, Backlund E: Black-white mortality differences by family income. Lancet 1992, 340(8815):346-50.

20. McGee DL, Liao Y, Cao G, Cooper RS: Self-reported health status and mortality in a multiethnic US cohort. Am J Epidemiol 1999, 149(1):41-6.

21. Marmot MG, Adelstein AM, Bulusu L: Office of Population Censuses and Surveys. Immigrant mortality in England and Wales 1970-1978. Causes of death by country of birth London: Her Majesty's Stationary Office; 1984.

22. Nazroo JY: The health of Britain's ethnic minorities. Findings from a national survey London: Policy Studies Institute; 1997.

23. Lindstrom M, Sundquist J, Ostergren PO: Ethnic differences in self reported health in Malmo in southern Sweden. J Epidemiol Community Health 2001, 55(2):97-103.

24. Wiking $E$, Johansson SE, Sundquist J: Ethnicity, acculturation, and self reported health. A population based study among immigrants from Poland, Turkey, and Iran in Sweden. J Epidemiol Community Health 2004, 58(7):574-82.

25. Sundquist J: Ethnicity, social class and health. A population-based study on the influence of social factors on self-reported illness in 223 Latin American refugees, 333 Finnish and 126 south European labour migrants and 841 Swedish controls. Soc Sci Med 1995, 40(6):777-87.

26. Nazroo JY: Genetic, cultural or socio-economic vulnerability? Explaining ethnic inequalities in health. Sociol Health Illness 1998, 20(5):710-30.

27. Smaje C: The ethnic patterning of health: new directions for theory and research. Sociol Health IIness 1996, 18:139-71.

28. Cirino PT, Chin CE, Sevcik RA, Wolf M, Lovett M, Morris RD: Measuring socioeconomic status: reliability and preliminary validity for different approaches. Assessment 2002, 9(2):145-55.

29. Geyer S: Einzelindikator oder Index? Maße sozialer Differenzierung im Vergleich [Single indicator or index? Comparison of measures of social differentiation]. Gesundheitswesen 2008, 70(5):281-8.

30. Lahelma E, Martikainen P, Laaksonen M, Aittomaki A: Pathways between socioeconomic determinants of health. J Epidemiol Community Health 2004, 58(4):327-32. 
31. Smith GD: Learning to live with complexity: ethnicity, socioeconomic position, and health in Britain and the United States. Am J Public Health 2000, 90(11):1694-8.

32. Allardt E: Att ha, att älska, att vara: Om välfärd i norden [On welfare in the Nordic countries: to have, to love, to be] Stockholm: Argos; 1975.

33. Elstad Jl: Social inequalities in health and their explanations Oslo: NOVA Norwegian Social Research; 2000

34. Sen A: Inequality reexamined Cambridge, Mass.: Harvard University Press; 1992.

35. Fritzell J, Lundberg O: Välfärd, ofärd och ojämlikhet - levnadsförhållanden under 1990-talet. Betänkande från Kommittén Välfärdsbokslut [Report from the Committee on the Welfare State: welfare, misfortune and inequality - living conditions in the 1990s] Stockholm: Fritzes; 2000. Report No.: SOU; 2000, 41

36. Larsen FB: Hvordan har du det? Selvvurderet helbred og ulighed i sundhed [How are you? Self-rated health and social inequality in health] Aarhus County: Unit of health promotion, Department of Public Health; 2003.

37. Krieger N, Williams DR, Moss NE: Measuring social class in US public health research: concepts, methodologies, and guidelines. Annu Rev Public Health 1997, 18:341-78.

38. Hansen EJ: Den centrale baggrundsvariabel er socialgruppeinddelingen [The central background variable is the social group classification]. Social Journal 1978, 11-12.

39. Oakes JM, Rossi PH: The measurement of SES in health research: current practice and steps toward a new approach. Soc Sci Med 2003, 56(4):769-84.

40. Statistics Denmark: Statistics Denmark. 2007 [http://www.dst.dk/homeuk. aspx], [cited 2007 Feb 1].

41. Ekholm O, Kjøller M, Davidsen M, Hesse U, Eriksen L, Christensen Al, Grønbæk M: Sundhed og sygelighed i Danmark 2005 \& udviklingen siden 1987 [Health and morbidity in Denmark in 2005 and the development since 1987] Copenhagen: National Institute of Public Health; 2006.

42. Mossey JM, Shapiro E: Self-rated health: a predictor of mortality among the elderly. Am J Public Health 1982, 72(8):800-8.

43. Søndergård Kristensen T: Selvvurderet helbred og arbejdsmiljø: er selvvurderet helbred et frugtbart og nyttigt begreb i arbejdsmiljøforskning og forebyggelse? [Self-rated health and work environment: is self-rated health a fruitful and useful concept in work environmental research and prevention?] Copenhagen: Work Foundation; 1998.

44. DeSalvo KB, Fan VS, McDonell MB, Fihn SD: Predicting Mortality and Healthcare Utilization with a Single Question. Health Serv Res 2005, 40(4):1234-46.

45. Idler EL, Benyami Y: Self rated health and mortality: a review of twentyseven community studies. J Health Soc Behav 1997, 38:21-37.

46. Chandola T, Crispin J: Validating self-rated health in different ethnic groups. Ethn Health 2000, 5:115-51.

47. Stafford M, Marmot M: Neighbourhood deprivation and health: does it affect us all equally? Int J Epidemiol 2003, 32(3):357-66.

doi:10.1186/1475-9276-10-5

Cite this article as: Andersen et al: Self-rated health, ethnicity and social position in a deprived neighbourhood in Denmark. International Journal for Equity in Health 2011 10:5.

\section{Submit your next manuscript to BioMed Central and take full advantage of:}

- Convenient online submission

- Thorough peer review

- No space constraints or color figure charges

- Immediate publication on acceptance

- Inclusion in PubMed, CAS, Scopus and Google Scholar

- Research which is freely available for redistribution 